\title{
Clinical teaching in Dermatology of Undergraduate Medical Students of Bangladesh
}

\author{
MS Islam ${ }^{1}$ Ismail Khan ${ }^{2}$ HK Talukder ${ }^{3}$, N Akther ${ }^{4}$
}

\begin{abstract}
This cross-sectional study was conducted with the objective to explore the practice of clinical teaching in Dermatology of undergraduate medical students of Bangladesh to identify the constraints and suggestions to improve the clinical teaching. The study also looked into the clinical competencies achieved by the students from available facilities provided by the institutes. The study was conducted at Dhaka Medical College (DMC) and Sir Salimullah Medical College (SSMC) from July 2008 to June 2009 . The students of $4^{\text {th }}$ year and $5^{\text {th }}$ year were the study population. Sample size was
\end{abstract} 273. After taking permission from concern authority data were collected through a self administered semi-structured questionnaire by convenient sampling. The study reflected that most of the clinical classes in Dermatology were taken by the junior teachers and mid level teachers. It was found that majority of clinical classes were held in the morning and afternoon, though a very few of the clinical classes are taken at night in Dermatology. The students viewed that the teachers follow the curriculum to conduct the clinical classes. The students agreed that they were benefited through those clinical classes and acquired how to examine the patients and to take history and other clinical skills. Majority of the respondents viewed that inadequate number of teachers and patients were one of the important barriers for clinical teaching in Dermatology. They suggested that the senior teachers should conduct clinical teaching with sufficient instructional materials and instruments. It was recorded that the clinical teaching in Dermatology should be integrated in the institutes. It was also proposed that sufficient number of relevant patients and adequate number of teachers should be ensured for imparting effective clinical teaching in Dermatology.

Key words Clinical Teaching, Curriculum and Dermatology.

1 Asst. Prof (skin \&VD) Centre for Medical Education, Dhaka.

${ }^{2}$ Prof \& Head of the department, Pharmacology \& Therapeutics DMC. Dhaka.

${ }^{3}$ Associate Prof \& course co-odinator Centre or Medical Education, Dhaka.

${ }^{4}$ Assistant Professor (Gynae \& Obs), SSMC, Dhaka

\section{Introduction}

Concept of clinical teaching: Clinical teaching is the teaching and learning focused on and sually directly involving patients and their problems.

It lies at the heart of medical education. At undergraduate level, medical schools strive to give students as much clinical exposure as possible; they are also increasingly giving students contact with patients earlier in the course (Fugill, 20051.For postgraduates, clinical teaching is the core of their professional development. How can a clinical teacher optimize the teaching and learning opportunities that arise in daily practice? A thematic review of the literature about teaching and learning in clinical settings found that clinical teaching is 'variable, unpredictable, immediate and lacks continuity (Irby, 1995). A survey of students' perceptions of 'good' and 'bad' teaching concluded that teachers' interpersonal behavior, how carefully they prepare and plan their teaching, and ability to 
run their session well, determine their worth as clinical teachers (Metcalfe and Mathura, 1995).

\section{Strengths and problems of clinical teaching:}

Learning in the clinical environment has much strength. It is focused on real problems in the context of professional practice. Learners are motivated by its relevance and through active participation. It is the only setting in which the skills of history taking, physical examination, clinical reasoning, decision making, empathy and professionalism can be taught and learnt as an integrated form. Despite these potential strengths, clinical teaching has been much criticized for its variability, lack of intellectual challenge, and haphazard nature. In other words, clinical teaching is an educationally sound approach, all too frequently undermined by problems of implementation (Pine et al, 2000).

\section{Common problems with clinical teaching:}

Common problems found with clinical teaching (Janada et al, 2004) are as follows- lack of clear objectives and expectation; focus on factual recall rather than on development of problem solving skills and attitudes; teaching pitched at the wrong level, usually too high; passive bservation rather than active participation of learners; inadequate supervision and provision of feedback; little opportunity for reflection and discussion; informed consent not sought from patients; lack of respect or privacy and dignity of patients and lack of continuity with the rest of the curriculum.

Challenges of clinical teaching: Although literature exposed many challenges of clinical teaching, the under mentioned events could be delineated specifically (Gerzina et al, 2005). These are- time pressures; competing demands of clinicians, administrators and researchers; often opportunistic makes planning more difficult; increasing numbers of students; fewer patients (shorter hospital stays; patients too ill or frail; more patients refusing consent); often under-resourced; clinical unfriendly environment in hospital ward; poor rewards and recognition for teachers.

The importance of planning: Many principles of good teaching should be incorporated into clinical teaching. One of the most important is the need for planning. Far from compromising spontaneity, planning provides structure and context for teacher and students, as well as a framework for reflection and evaluation. Students recognize preparation as evidence of a good clinical teacher (Pessian and Bekett, 2004).

Importance of clinical teaching in dermatology: Clinical teaching is part of a doctor's professional life, weather it takes place in clinics or in hospitals, with undergraduates, postgraduate trainees or colleagues (Parsell \& Bligh, 2001). Dermatology is the one of the most clinical subject. Without effective clinical teaching no one can diagnose Dermatological patient properly.

Effective teaching depends crucially on the teacher's communication skills. Two important areas of communication for effective clinical teaching are questioning and giving explanations (Pine et al, 2000). It is important to allow learners to articulate areas in which they are having difficulties or which they wish to know more about. Clinical teaching is described by several authors a three stage process for both learners and teachers that involves: prior planning and preparation; teaching with patients and charting, giving feedback and reflection.

Teaching on the wards: Despite a long and worthy tradition, the hospital ward is not an ideal teaching venue. Nonetheless, with preparation and forethought, learning opportunities can be 
maximized with minimal disruption to staff, patients, and their relatives. Approaches include teaching on wards and clinics; students seeing patients on their own then reporting back, with or without a follow up visit to the bedside for further discussion; and shadowing, when learning will inevitably be more opportunistic. Dermatological schools need to create the conditions that encourage teaching innovation through providing clinical environment (Pee et al, 2003). Key issues are careful selection of patients; ensuring ward staff know what's happening; briefing patients as well as students; using a side room for discussions about patients; and ensuring that all relevant information such as records and x-ray films are available.

Teaching in out patient departments: Most clinical teaching in dermatology is in the out patient department. Ideally we should provide isolated teaching clinics for our students, but most hospital this is not possible. Instead undergraduate has to be combined with clinical work and postgraduate training. Successful teachers teach in short 'bites', making the most of learning opportunities balanching the conflicting demands of patients, medical students and other trainees. (Spencer 2003, Slotnick 1996, Persell \& Bligh, 2001).

Teaching during consultations has been much criticized for not actively involving the learners. With relatively little impact on the running of a clinic, students can participate more actively. For example, they can be asked to make specific observations, write down thoughts about differential diagnosis or further tests, or note any questions - for discussion between patients. A more active approach is hot seating. Here, the student leads the consultation, or part of it. His or her findings can be checked with the patient, and discussion and feedback can take place during or after the encounter. Students, although daunted, find this rewarding. A third model is when a student sees a patient alone in a separate room, and is then joined by the tutor. The student then presents their findings, and discussion follows. A limitation is that the teacher does not see the student in action. It also inevitably slows the clinic down, although not as much as might be expected. In an ideal world it would always be sensible to block time in a clinic to accommodate teaching.

The patient's role: It is a safe rule to have no teaching without a patient for a text and the best teaching is that taught by the patient himself is well known. The importance of learning from the patient has been repeatedly emphasized. For example, generations of students have been exhorted to listen to the patient - he is telling you the diagnosis. Traditionally, however, a patient's role has been essentially passive, the patient acting as interesting teaching material, often no more than a medium through which the teacher teaches. As well as being potentially disrespectful, this is a wasted opportunity, Not only can patients tell their stories and show physical signs, but they can also give deeper and broader insights into their problems. Finally, they can give feedback to both learners and teacher. Through their interactions with patients, clinical teachers knowingly or unknowingly have a powerful influence on learners as role models.

\section{Working effectively and ethically with patients}

Thinking carefully about which parts of the teaching session require direct patient contact, is it necessary to have a discussion at the bedside and obtaining consent from patients before the students arrive and ensuring that students respect the confidentiality of all information relating to the patient, verbal or written. It is better to brief the patient before the session - purpose of the teaching 
session, level of students' experience, how the patient is expected to participate. It is wise to involve the patient in the teaching as much as possible and asking the patient for feedback communication and clinical skills, attitudes, and bedside manner. Debriefing the patient after the session - they may have questions, or sensitive issues may have been raised. Student experience must be recorded in order to judge the competences accumulated (Holbrook et al, 2008)

\section{Materials and Methods}

Study design

Cross-sectional descriptive study.

\section{Study period}

July 2008 to June 2009

\section{Place of study}

Dhaka Medical College and Sir Salimullah Medical College of Dhaka were included in this study.

\section{Study population}

Students of $4^{\text {th }}$ and $5^{\text {th }}$ year.

\section{Inclusion criteria}

1. Those students were available during the period of data collection.

2. Those were willing to answer the written questions of the questionnaires.

\section{Exclusion criteria}

Who did not willingly complete questionnaires?

\section{Sample size}

273 students were included in this study.

\section{Sampling technique}

Sampling technique was convenient.

\section{Research instruments}

One semi-structured self-administered questionnaire was used to collect data. The instrument developed and finalized after pre-testing.

\section{Pretest}

1. The instruments were pre tested at National medical college, Dhaka.

2. The medical college was used for pretest that was other than the medical college selected for this study.

3. To develop and finalize the instruments information were collected from 30 students (15 from each $4^{\text {th }}$ and 15 from $5^{\text {th }}$ year students) of each medical college.

\section{Procedure of data collection}

- Researcher initially applied to the principals of concerned Medical Colleges selected for pretest and study.

- Director CME forwarded the applications.

- After getting permission from the principals of the institutes the researcher met with the concerned head of the departments to inform him about the purpose and to get scope to collect information from the students.

- Verbal consent were taken from the respondents before data collection

\section{Data processing and analysis}

The collected questionnaires were edited, and arranged manually. On the basis of the key variables, a master-sheet was prepared using computer software SPSS. The collected data were duly entered, processed and analyzed. Interpretations were made subsequently. 


\section{Result}

Table 1: Designation of the teachers who conduct the clinical classes in Dermatology $(n=273)$

\begin{tabular}{|l|c|c|c|}
\hline $\begin{array}{l}\text { Designation of } \\
\text { teachers who } \\
\text { conducted the } \\
\text { clinical classes }\end{array}$ & \multicolumn{2}{|c|}{ Frequency } & Percentage \\
\cline { 2 - 4 } & 4th year & 5th year & \\
\hline Professor & 49 & 30 & $28.5 \%$ \\
\hline Associate Prof & 37 & 28 & $23.8 \%$ \\
\hline Assistant prof & 32 & 19 & $18.68 \%$ \\
\hline Registrar & 84 & 77 & $58.97 \%$ \\
\hline $\begin{array}{l}\text { Assistant } \\
\text { Registrar }\end{array}$ & 19 & 9 & $10.25 \%$ \\
\hline \multicolumn{3}{|l|}{} \\
\hline
\end{tabular}

Table no. 1 has shown out of 273 students' majority think the teachers who conduct clinical classes in dermatology are registrars $(58.97 \%)$. There were some students viewed that these classes also conducted by the professor $(28.5 \%)$, associate professor $(23.8 \%)$ assistant professor $(18.68 \%)$ and assistant registrar $(10.25 \%)$.

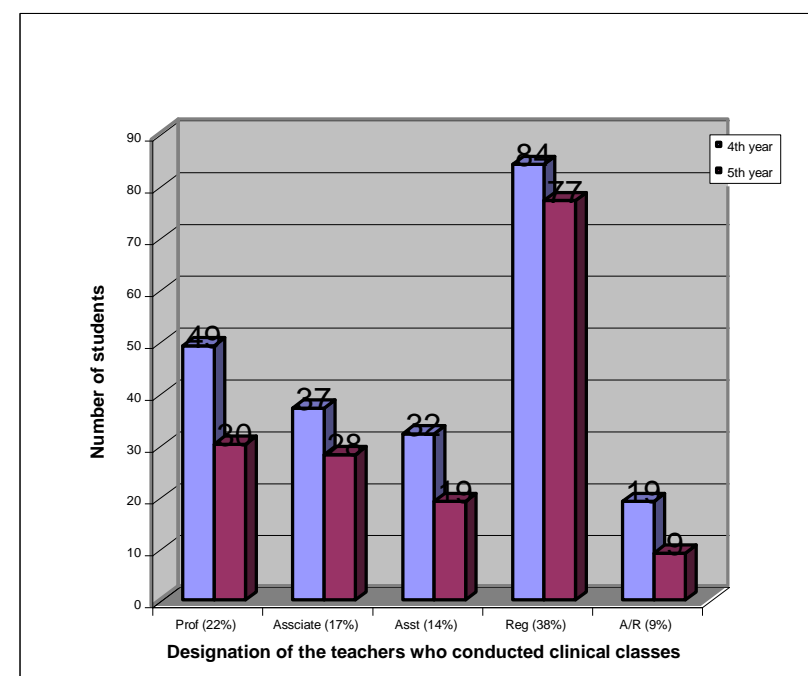

$(n=273)$

Graph 1: Graphical presentation of clinical class conduction in Dermatology

Graph no.1 has shown that most of the clinical classes were taken by registrar $(58.97 \%)$, professor $(28.5 \%)$, associate professor $(23.8 \%)$, assistant professor $(18.68 \%)$ and assistant registrar $(10.25 \%)$.
Table 2: Total hours of clinical classes in Dermatology

\begin{tabular}{|c|c|c|c|}
\hline $\begin{array}{l}\text { Total hours of } \\
\text { clinical classes }\end{array}$ & 4th year & 5 th year & Percentage \\
\hline $\begin{array}{cc}4 & \text { hours } \\
(80 \%) & \\
\end{array}$ & 3 & 11 & $5.12 \%$ \\
\hline $\begin{array}{cc}3.5 & \text { hours } \\
(70 \%) & \\
\end{array}$ & 6 & 19 & $9.15 \%$ \\
\hline $\begin{array}{ll}3 & \text { hours } \\
(60 \%) & \end{array}$ & 24 & 15 & $14.28 \%$ \\
\hline $\begin{array}{ll}2.5 & \text { hours } \\
(50 \%) & \end{array}$ & 33 & 22 & $20.14 \%$ \\
\hline $\begin{array}{ll}2 & \text { hours } \\
(40 \%) & \\
\end{array}$ & 41 & 25 & $24.17 \%$ \\
\hline $\begin{array}{cc}1.5 & \text { hours } \\
(30 \%) & \end{array}$ & 36 & 16 & $19.04 \%$ \\
\hline $\begin{array}{ll}1 & \text { hour } \\
(20 \%) & \\
\end{array}$ & 18 & 4 & $8.05 \%$ \\
\hline Total & 161 & 112 & $100 \%$ \\
\hline
\end{tabular}

$(n=273)$

[The hours of clinical classes derived from the percentage of clinical classes (after calculation) compared to total classes.]

Table no. 2 has shown the distribution of the students by their opinion regarding the total hours of clinical teaching. Here most of the respondents $(24.17 \%)$ viewed that they had two hour of clinical teaching and $20.14 \%$ had viewed that their clinical teaching were 2.5 hours. Only $5.12 \%$ viewed that clinical classes were 4 hours.

Table 3: Selection of topics for clinical teaching in Dermatology

\begin{tabular}{|l|c|c|c|}
\hline $\begin{array}{l}\text { From where } \\
\text { topics were } \\
\text { selected }\end{array}$ & \multicolumn{2}{|l|}{ Frequency } & Percentage \\
\cline { 2 - 3 } & $\begin{array}{l}\text { 4 th } \\
\text { year }\end{array}$ & $\begin{array}{l}\text { 5th } \\
\text { year }\end{array}$ & \\
\hline Curriculum & 87 & 49 & $49.81 \%$ \\
\hline $\begin{array}{l}\text { Academic } \\
\text { calendar }\end{array}$ & 58 & 46 & $38.09 \%$ \\
\hline $\begin{array}{l}\text { Decision by the } \\
\text { head }\end{array}$ & 31 & 22 & $19.41 \%$ \\
\hline Pt availability & 21 & 19 & $14.65 \%$ \\
\hline Others & 2 & 4 & $2.19 \%$ \\
\hline
\end{tabular}

$(\mathbf{n}=\mathbf{2 7 3})$ 
Table no. 3 has shown the topic considers conducting clinical teaching in which the highest numbers of percentage $(\mathbf{4 9 . 8 1 \%})$ are curriculum and second highest $(38.09 \%)$ number of percentage were academic calendar.

Table 4: Level of benefit of clinical classess in Dermatology

\begin{tabular}{|l|c|c|c|}
\hline Level of benefit & 4th year & 5th year & Percentage \\
\hline Highly benefited & 29 & 26 & $20.14 \%$ \\
\hline Benefited & 99 & 64 & $59.07 \%$ \\
\hline Slightly benefited & 31 & 20 & $18.68 \%$ \\
\hline Not benefited & 2 & 2 & $1.46 \%$ \\
\hline Total & 161 & 112 & $100 \%$ \\
\hline
\end{tabular}

Table no 4 focused the opinion of students how much benefits the students get from the clinical teaching. Majority of the students $59.07 \%$ agreed that they are benefited and only a few percentage $1.46 \%$ of students opined they are not benefited.

Table 5: Acquired skills by the clinical classes in Dermatology

\begin{tabular}{|l|c|c|c|}
\hline $\begin{array}{l}\text { Acquired Skills by } \\
\text { the clinical classes }\end{array}$ & \multicolumn{2}{|c|}{ Frequency } & \\
\hline 4th year & $\mathbf{5}^{\text {th }}$ year & Percentage \\
\hline 1. History taking & 156 & 104 & $95.23 \%$ \\
\hline $\begin{array}{l}\text { 2. Investigation } \\
\text { writing }\end{array}$ & 71 & 72 & $52.38 \%$ \\
\hline $\begin{array}{l}\text { 3. Diagnosis of } \\
\text { disease }\end{array}$ & 106 & 94 & $73.26 \%$ \\
\hline $\begin{array}{l}\text { 4. Prescription } \\
\text { writing }\end{array}$ & 14 & 10 & $8.79 \%$ \\
\hline $\begin{array}{l}\text { 5. Counseling of } \\
\text { pts/attends. }\end{array}$ & 78 & 56 & $49.08 \%$ \\
\hline $\begin{array}{l}\text { 6. Differentials } \\
\text { diagnosis. }\end{array}$ & 86 & 83 & $61.90 \%$ \\
\hline \begin{tabular}{l} 
7. Pt examination \\
\hline $\begin{array}{l}\text { 8. Interpretation of } \\
\text { investigation }\end{array}$
\end{tabular} & 150 & 99 & $91.20 \%$ \\
\hline $\begin{array}{l}\text { 9. Treatment plan } \\
\text { 10.Operative } \\
\text { procedure }\end{array}$ & 54 & 56 & $40.65 \%$ \\
\hline $\begin{array}{l}\text { 11. Integration of } \\
\text { theory and practice }\end{array}$ & 39 & 44 & $45.05 \%$ \\
\hline
\end{tabular}

$(\mathrm{n}=273)$

Respondent's opinion regarding the skills the students learn through clinical teaching have been shown in the table no.5. From the table it is evident that most of the respondents viewed that through clinical teaching students learn history taking (95.23\%). A major portion of respondents agreed that students learn how to examine the patient $(91.40 \%)$
Table 6: Barriers of clinical teaching in Dermatology

\begin{tabular}{|c|c|c|c|}
\hline $\begin{array}{l}\text { Barriers that } \\
\text { hampered the } \\
\text { clinical teaching }\end{array}$ & Freq & ency & \\
\hline in Dermatology & $\begin{array}{l}\text { 4th yea } \\
\text { year }\end{array}$ & 5th & Percentage \\
\hline $\begin{array}{l}\text { 1. Patients } \\
\text { inadequacy }\end{array}$ & 29 & 24 & $19.41 \%$ \\
\hline \begin{tabular}{|l|l} 
2. Teacher \\
inadequacy
\end{tabular} & 69 & 32 & $36.99 \%$ \\
\hline $\begin{array}{l}\text { 3. Most of the time } \\
\text { classes do not held }\end{array}$ & 40 & 8 & $17.58 \%$ \\
\hline $\begin{array}{l}\text { 4. Theories are } \\
\text { taught more }\end{array}$ & 106 & 75 & $66.30 \%$ \\
\hline $\begin{array}{l}\text { 5. Learning is } \\
\text { hampered due to } \\
\text { excess no of } \\
\text { student }\end{array}$ & 106 & 68 & $63.23 \%$ \\
\hline $\begin{array}{l}\text { 6. Unavailability of } \\
\text { patient included in } \\
\text { the syllabus }\end{array}$ & 42 & 30 & $26.37 \%$ \\
\hline $\begin{array}{l}\text { 7. Inadequacy of } \\
\text { instruments }\end{array}$ & 69 & 46 & $42.12 \%$ \\
\hline $\begin{array}{l}\text { 8. Teachers cannot } \\
\text { instruct properly }\end{array}$ & 59 & 47 & $38.82 \%$ \\
\hline $\begin{array}{l}\text { 9. Classes are not } \\
\text { held in time }\end{array}$ & 65 & 38 & $37.72 \%$ \\
\hline $\begin{array}{l}\text { 10. Repetition of } \\
\text { same topic } \\
\text { unnecessarily }\end{array}$ & 59 & 47 & $42.49 \%$ \\
\hline $\begin{array}{l}\text { 11. Sometimes } \\
\text { patient attendant } \\
\text { does not allow } \\
\text { patient } \\
\text { examination }\end{array}$ & 44 & 41 & $31.13 \%$ \\
\hline $\begin{array}{l}\text { 12. Less co- } \\
\text { operation of staff. }\end{array}$ & 53 & 40 & $34.06 \%$ \\
\hline
\end{tabular}

Table no 6 has shown the respondents opinion regarding the barriers of clinical teaching. It is found that most of them viewed that clinical teaching is hampered due to theories are taught more $(66.30 \%)$ and excess number of student (63.23\%). Major portion of respondents agreed that clinical teaching is also hampered due to inadequacy of instruments $(42.12 \%)$ and repetition of same topic unnecessarily (42.49\%). A very good number of students viewed that teachers cannot instruct properly $(38.82 \%)$, less co-operation of staff $(34.06 \%)$, unavailability of patient included in the syllabus (26.37\%) and most of the time classes do not held (5\%). Only few of respondents viewed that patient inadequacy (17.58\%) hampered the clinical teaching. 
Table 7: Suggestion for improving the clinical classes in Dermatology

\begin{tabular}{|l|c|c|c|}
\hline $\begin{array}{l}\text { Suggestions for } \\
\text { improving the clinical } \\
\text { classes }\end{array}$ & \multicolumn{2}{|l|}{$\begin{array}{l}\text { Frequency } \\
\text { 4hear } \\
\text { year }\end{array}$} & \multicolumn{1}{|c|}{$\mathbf{5}^{\text {th }}$} \\
\hline $\begin{array}{l}\text { 1. Sufficient instrument } \\
\text { should be available }\end{array}$ & 97 & 48 & $53.11 \%$ \\
\hline $\begin{array}{l}\text { 2. Sufficient materials } \\
\text { should be available }\end{array}$ & 76 & 38 & $49.09 \%$ \\
\hline $\begin{array}{l}\text { 3. Sufficient beds should } \\
\text { be available }\end{array}$ & 55 & 40 & $54.91 \%$ \\
\hline $\begin{array}{l}\text { 4. Provision of } \\
\text { examining all types of } \\
\text { patients }\end{array}$ & 94 & 60 & $56.41 \%$ \\
\hline $\begin{array}{l}\text { 5. Increasing no of } \\
\text { teachers }\end{array}$ & 93 & 30 & $71.09 \%$ \\
\hline $\begin{array}{l}\text { 6. Sufficient no of } \\
\text { patients }\end{array}$ & 47 & 23 & $25.64 \%$ \\
\hline $\begin{array}{l}\text { 7. More classes taken by } \\
\text { the senior teacher }\end{array}$ & 127 & 96 & $81.68 \%$ \\
\hline $\begin{array}{l}\text { 8. Teachers class should } \\
\text { aim at students benefit }\end{array}$ & 131 & 85 & $79.12 \%$ \\
\hline $\begin{array}{l}\text { 9. Student should get the } \\
\text { opportunity to examine } \\
\text { the patient }\end{array}$ & 102 & 81 & $67.03 \%$ \\
\hline $\begin{array}{l}\text { 10. No of student should } \\
\text { be limited }\end{array}$ & 111 & 63 & $63.73 \%$ \\
\hline $\begin{array}{l}\text { 11. Integration of } \\
\text { clinical and other classes }\end{array}$ & 137 & 72 & $76.53 \%$ \\
\hline $\begin{array}{l}\text { 12. Others } \\
\text { (n=273) }\end{array}$ \\
\hline
\end{tabular}

Table no 7 has shown the most of the respondent $(81.68 \%)$ suggest 'senior teachers should take the classes, teachers classes aim at students benefit $(79.12 \%)$ and integration of clinical and non clinical teaching $(76.53 \%)$. Some of them $(53.11 \%)$ also viewed that sufficient instruments, provision of examining all types of patients $(56.41 \%)$, increasing number of teachers $(71.09 \%)$ and student should get the opportunity to examine the patients $(67.03 \%)$.

Table 8: Time of clinical teaching in Dermatology

\begin{tabular}{|l|c|c|c|}
\hline $\begin{array}{c}\text { Schedule of clinical } \\
\text { classes }\end{array}$ & $\mathbf{5}^{\text {th }}$ year & $\mathbf{4}^{\text {th }}$ year & Percentage \\
\hline Morning & 58 & 108 & $60.8 \%$ \\
\hline Evening & 12 & 3 & $5.49 \%$ \\
\hline Afternoon & 37 & 36 & $26.73 \%$ \\
\hline \multicolumn{3}{|c}{$(\mathrm{n}=273)$} \\
\hline
\end{tabular}

Table no 8 shown the time of clinical classes. The highest number of respondents $(60.8 \%)$ opined the clinical classes are held in the morning. A few numbers of respondents (5.49\%) opined that clinical classes are held in evening.

\section{Discussion}

In this study the students' opinion had been taken to compare their views on same questionnaire. Here students of two medical colleges participated disproportionately as for example student of Dhaka medical college (DMC) were $173\left(4^{\text {th }}\right.$ year 111 and $5^{\text {th }}$ year 62) and Sir Salimullah medical college (SSMC) were $100\left(4^{\text {th }}\right.$ year 50 and $5^{\text {th }}$ year 50$)$. The total numbers of participants of 5th year students' were 112 and the $4^{\text {th }}$ year were 161 . The number of $5^{\text {th }}$ year participant was lower than the number of $4^{\text {th }}$ year due to the $5^{\text {th }}$ year students were engaged for final professional examination and their lecture classes were suspended.

It was observed that most of the clinical classes were conducted by the registrar. Sometimes conducted by the Professor and Associate Professors. The assistant registrar rarely conducts the clinical classes. These findings might vary if the data were collected outside medical colleges of Dhaka because there is no registrar post (except sylhet medical college) in medical college. Out side

Dhaka there was also no assistant registrar post in medical colleges. This scenario indicated that undergraduate medical education would require to be updated by maintaining student-teacher ratio to keep pace with ongoing development within the profession. Regarding the respondent's opinion usually when the clinical classes were held, the majorities $(60.8 \%)$ viewed that these were held in the morning. But only few of them viewed that these classes were held at afternoon $(26.73 \%)$ and night( $5.49 \%)$.Availability of dermatological patients in the morning was the reason for this finding. The dermatological patients were unavailable in the later part of the day due to less hospital bed for admission. Probably this was the reason for the clinical classes not usually held in the afternoon. On the other hand all Dermatologists were allowed to practice at his or her chamber beyond the office hour. This might be the reason for the clinical classes are not taken at night.

The respondents had given their views regarding the percentage of clinical teaching that was practicing at their institute compared to total classes. It was observed that more than $20 \%$ respondents viewed that 2 hours of the total classes are clinical type. These finding were almost consistent with the division of respondents into different categories. But we know the duration of clinical classes were two and half-hours per day, which means it was about $50 \%$ of the academic hours (class routines). All the institutes under this 
study started at 8 am and closed at 2 pm with onehour leisure (11to 11.30am and 1to1.30 pm).

The reasons for the high proportion of clinical classes within the academic hours were that the lecture and tutorials were almost finished when the researcher was collecting data. It should be mentioned that during the period of data collection professional examination was knocking at the doors and at that times students concentrated on clinical exercise instead of attending the clinical classes. This feature matched with the sessions of different colleges in UK (Derringer, 2005).

It was a question to respondents that which items should be considered for conducting clinical teaching in Dermatology department. Majority of the respondent considered curriculum (49.81\%) and academic calendar (38.09\%) for this. Decision by the head of the department and availability of patients were also taken in consideration by some respondent, where as integration with other department was a very rare practice. Definitely availability of the patients was the most important issue for clinical teaching because of some suitable patients of every disease was not always available.

Regarding the benefit of clinical teaching 59.07\% respondents viewed that they were benefited having the clinical class in their institute. There were only $18.68 \%$ respondents who viewed that the benefit wais slight and $1.46 \%$ of respondents viewed that they were not benefited with these clinical classes. The respondents also opined that they were learned about the history taking, patient examination, diagnosis of diseases, differential diagnosis of disease, counseling of patient/attendant and planning of treatment from the clinical teaching (Table 5).

The respondents had mentioned a number of barriers existing in the institute that hampered clinical teaching. The most important of these were- giving more emphasis on theories, excess number of students, inadequate number of teachers and instruments .Teachers could not instruct properly, unnecessary repetition of same topics, unwillingness to examination of patients. Non cooperation of staff also considered as barriers by the respondents (DGHS rules 2004 for Medical and Dental college approval). All these comments were dividing the respondents into different categories (Table 6).

The respondents had mentioned a number of suggestions for the development of clinical teaching. The most important suggestions were- the senior teachers should take the clinical classes, classes should aim at students' benefit and there should be integration of clinical and non-clinical classes. Some of them gave emphasis to limit the number of students, to got the opportunity for examining the patient, availability of sufficient instruments, materials and bed (Table 7).

All the students and teacher were highly engaged in their academic activities and for their professional exercise in the institutes. It was difficult to collect data from the students during their busy schedule. But the researcher thought that students who had newly enrolled in the clinical year might not give sufficient information regarding the clinical classes of the year. But when the researcher started data collection it was difficult to administer questionnaire to students. The researchers who wish to study in this field should start data collection a little bit earlier (one to two months).

\section{Conclusion}

Clinical teaching is the most important area of medical education. This study was done to find out the present scenario of clinical teaching in Dermatology of undergraduate medical students of Bangladesh. This study explored the views of 273 students of two renowned institutes of Bangladesh. This study reflected the current status of clinical teaching in dermatology of undergraduate medical students of the country. It was observed that there was huge scarcity of professor, associate professors, assistant professors, registrar and assistant registrars who conduct the clinical teaching. The unavailability of instruments, bed and patients played the important barriers against achieving clinical skills by the students. Although having these constrains teachers and students were trying to follow the curriculums to achieve all necessary clinical competencies. Though this study was conducted with a number of limitations but it was tried to document the major issues in the field of clinical teaching in Dermatology of Bangladesh, which would guide for further research and development of the clinical teaching in future.

\section{Recommendation}

- Number of teachers should be increased to facilitate the clinical teaching in Dermatology.

- Number of beds for patients should be increased in hospitals so that students get opportunity to examine the patients.

- Teaching materials and teaching aids should be optimum in the out patient department and indoor and should be available during conducting clinical teaching.

- To ensure availability of patient in the teaching institutes all alternate approach should be taken, so that students should 
have adequate clinical exposure and achieve clinical competences regarding the common dermatological problems in the country.

- Wide range training programs for the clinical teachers.

\section{Reference}

Derrigner, K.A (2005) Undergraduate orthodontic teaching in UK dental schools. British Dental Journal, 198(4),232-244

Fugill, M. (2005) Teaching and learning in dental student clinical practice. EUR J Dental Education, 9,131-136

Gerzina, Tania, M.D., Mclean Ph., \& Tim. (2005) Dental teaching: perception of students and teachers, Milieu in dental school and practice. Journal of dental education, 1377-1384

Parsell, G. \& Bligh, J. (2001) Recent perspectives on clinical teaching Medical

Education,35,409-414

Goldenberg, D. \& Beyar, R. (2000) The medical school Web site: medical education's newest tool. Isr Med Assoc J, 2,797-800.

Gordon, J., Hazlett, C. \& Ten, C.O. (2000) Strategic planning in medical education: enhancing the learning environment for students in clinical settings. Med Educ, 34,841-50.

Harden, R.M. \& Hart, I.R. (2002) An international virtual medical school (IVIMEDS): the future for medical education? Med Teach, 24,261-7.

Holbrook, W.P. (2008) Balancing the role of the dental school in teaching, research and patient care; including care for underserved areas. Eur J Dental education, 12,161-166

Irby, D.M. (1995) Teaching and learning in ambulatory care settings: a thematic review of the literature. Acad Med,70 (10),898-931.

Janada, M. \& Schittek. (2004) Simulation of patient encounters using a virtual patient in periodontology instruction of dental students: design, usability and learning effect in history taking skills. Eur J Dental Educ, 8,111-119

Metcalfe, D.H. \& Mathura, M. (1995) Students' perceptions of good and bad teaching: report of a critical incident study. Med Educ, 29,193-7.
Parsell, J. \& Bligh, J. (2001) Recent perspectives on clinical teaching. Med Educ,35, 409-14.

Paukert, J.L. \& Richards, B.F. (2000) How medical students and residents describe the roles and characteristics of their influential clinical teachers. Acad Med, 75 (8),843-5.

Pessian, F. \& Beckett, H.A. (2004) Record keeping by undergraduate dental students: A clinical audit. British dental journal, 197(5),703-705

Pine, Cynthia, M., Goldrick, M. \& Pauline, M. (2000) Application of behavioral science teaching by UK dental undergraduate. Eur $J$ Dental Education, 4,49-56

Slotnick, H.B. (1996) How doctors learn: the role of clinical problems across the medical schoolto-practice continuum. Med Educ, 71,28-34.

Spencer, J. (2003) Learning and teaching in the clinical environment. Be Med J, 326, 591-4.

Spencer, J., Blackmore, D., Heard, S., McCrorie, P., McHaffie, D., \& Scherpbier, A. (2000) Patient-orientated learning: a review of the role of the patient in the education of medical students. Med Educ, 34,851-7.

The General Medical Council Education Committee. Tomorrow's Doctors.

Recommendations on Undergraduate Medical Education. (2002) General Medical Council: London. 